\title{
Resilient urban morphology to the flood risk in the final stretch of the Girona River (Alicante province)
}

\author{
José Sergio Palencia Jiménez ${ }^{1}$, Eric Gielen², Yaiza Pérez Alonso² \\ ${ }^{1}$ Instituto del Transporte y Territorio. Departamento de Urbanismo. \\ Universitat Politècnica de València. Valencia, Spain \\ ${ }^{2}$ Departamento de Urbanismo. Universitat Politècnica de València. Valencia, Spain \\ E-mail: jpalenci@urb.upv.es, egielen@urb.upv.es, yaipeal@urb.upv.es
}

\begin{abstract}
The Litoral-Cota 100 zone represents approximately 25\% of the total area of the Region of Valencia and concentrates more than $70 \%$ of the urban area. One of the consequences of this situation has been the high urban developments produced in the last 50 years. The Valencian Community has a river flood hazard mapping, according to which, in the Litoral area, more than $80 \%$ of the flood hazard is concentrated. As a result of the experienced urban development and the extent of flooding, there is a significant number of people and property exposed to flood hazards. In order to analyze in detail the urban morphology on the coast and its interaction with floods, research has focused on the specific area of the final section of the Girona River, in the province of Alicante. Specifically, in the municipalities of Els Poblets, El Verger, Denia and Beniarbeig, located in the surroundings of the Girona River, very different urban morphologies have been generated that are not adapted to the existing flood hazard. The analysis carried out allows us to conclude that, despite the significant expansion of urban land, existing urban morphology offers ample possibilities to reduce the risk of flooding. It is proposed the integration of overflows in the built city, avoiding the consolidation of non-built land and designing particular measures on affected buildings. These measures of adaptation to the problem will generate a resilient urban morphology.
\end{abstract}

Keywords: Flood risk, Flood hazards, Land use, Resilient Urban, Girona River.

\section{Introduction}

The Valencian Community is a territory that, due to its climatic conditions and its physiographic characteristics, is susceptible to experiment frequent and important floods. If we add to this situation the alterations to which the territory has been subjected as result of the anthropic actions, such as urban developments and infrastructures, it is observed that the material, environmental and human damages have increased significantly from the 80 s to the present.

The Valencian Community has the so-called TerritorialAction Plan onFlood Risk Prevention in the Valencian Community (PATRICOVA), in force since January 28, 2003, which was revised and approved on October 29, 2015, by Decree 201 / 2015 of the Consell. The purpose of PATRICOVA is to provide the Valencian Community with an instrument for improving knowledge and risk assessment, preventive management of land uses, cooperation and administrative collaboration, and management of flooding in the green infrastructure.

Taking into account the previous objectives and territorial characteristics defined in the Territorial Strategy of the Valencian Community (ETCV), approved by Decree 1/2011, of 13 January, of the Consell, which divides the territory of the Valencian Community into three major Geographical areas according to 
urban and environmental configuration criteria, which have been denominated Coastal Area Level 100, Middle Belt and Rural System, we find very different flood conditions in each of the referred areas.

In this sense, more than $80 \%$ of the surface subject to risk of flooding in the Valencian Community is located in the Coastal Zone Level 100, which represents $25 \%$ of the Valencian territory, mainly due to the presence of river and dry riverbeds mouths, and wetlands. It also concentrates a population that exceeds $80 \%$ of the entire Comunitat, as a result of this occupation, a large area is used for urban uses, equipment, economic activities and infrastructures, of which $13 \%$ of these uses are affected by risk of flood according to PATRICOVA, a significant figure if we compare it with the areas corresponding to the Middle Belt and the Rural System, with conditions around $2 \%$. This situation requires a singular attention on the part of all the administrations related to the land uses and the risks of flood, in view of the high impact to which the Coastal Zone - Level 100 is exposed by flood risk.

The goal of PATRICOVA is to reduce this impact from a dual perspective, on the one hand, through the implementation of structural measures that mitigate the risks detected in the floodplain areas, and on the other hand by orienting urban development towards areas with lower risk of flooding.

However, in view of the current situation and the scope of the actions envisaged, we consider it necessary to act on the constructed city, analyzing in each case its urban morphology and the incidence of flooding, trying to integrate both aspects in order to make the city built more resilient to the risk of flood avoiding the increase of the same due to the non adaptation of the city and the occupation of inadequate spaces.

\section{Methodology}

For the development of the research, the Girona river basin and the Portelles ravine have been selected as a pilot basin, located to the north of the province of Alicante, which integrates the three territorial areas defined in the ETCV.
The consideration of the ravine of Portelles is due to the fact that both courses are very linked because the overflows of the Girona river significantly affect the ravine of Portelles, being able to consider both as a unique system.

Data have been generated relating to land uses, the evolution of urban morphology through building constructions and the extent of flooding according to different scenarios. From here, we have determined the extent of flood risk and propose solutions that make it more resilient the municipalities of Beniarbeig, El Verger, Denia and Els Poblets, in the vicinity of the Girona river and the ravine Portelles object of the investigation.

Regarding land uses, it was considered necessary to evaluate the effect of changes in soil cover on the generation of surface runoff, which have a significant effect on the extent of flood events, in order to determine if the transformations Produced in the basin have aggravated the risk of flooding.

For this purpose, the land use mapping of the year 2011, according to the Land Use Information System of Spain (SIOSE), has been arranged, in the area of the Girona river basin and the ravine of Portelles. On the other, a map of the land uses corresponding to the year 1956 was made, making use of the following sources of information: Aerial photograph corresponding to the American flight of year 1956 of the National Geographic Institute and the characteristic leaves of the General Direction of the Cadastre, between the years 1955 and 1964.

With the information mentioned, the methodology developed has been based on photointerpretation from the aerial photographs, and its contrast with the leaves characteristic of the Cadastre, for the identification and delimitation of the different units that were wanted to be mapped, assigning them one of the ten categories of soil that were defined.

As for the evolution of urban morphology and its incidence on floods, the development of the building, its typology and the occupation of flood areas between 1956 and 2013 were analyzed in order to evaluate the increase of damages due to exposure to floods.

With the aim of delving into the effects of floods on territorial transformations and their 
morphology, it has been analyzed for each of the municipalities that integrate the field of research which has been the growth in their constructions from 1956 to 2013, according to data published by the General Direction of Cadastre, focusing this article on the municipalities of Beniarbeig, El Verger, Dènia and Els Poblets. The municipalities partially affected by the river basins of the Girona river and Portelles ravine have been analyzed exclusively in the areas affected by these basins.

\section{Measurement and analysis}

Land uses.

As explained in the methodology, the effect of changes in land use between 1956 and 2011 has been analyzed. In order to compare the two cartographies and their effects, they were homogenized by establishing ten categories or coverages of the land uses, which have been grouped as follows:

Forest trees; Crops; Hydrography (dry riverbeds); Scrubland; Pastureland; Beaches, dunes and sandy beaches; Hard rock; Artificial soil; Road network and Burned areas.
Once the land use maps for the years 1956 (Figure 1) and 2011 (Figure 2) have been defined, the areas of each coverage have been determined, considering that the basins of the Girona river and Portelles ravine have been modified as a consequence of the anthropic alterations in the territory. However, it should be borne in mind that the two maps generated are products derived from images obtained by different sensors, so that the starting data have diverse spatial, temporal and spectral characteristics.

As mentioned above, it can be seen that the total area of the watersheds studied does not have the same surface area, being higher in 1956, which has been reduced by the various territorial transformations, in particular by the developed urbanization processes.

Another point that should be made, is that in the 1956 land uses mapping, the burned areas were not reflected, in the absence of such information. However, the forest cover identified is much lower in 1956, as shown in Table 1, which indicates either abundant deforestation due to the exploitation of the resource wood and charcoal, or the existence of large forest fires.

Table 1.

Area and percentage of land uses in the years 1956 and 2011.Source: Own elaboration.

\begin{tabular}{|c|c|c|c|c|}
\hline \multirow[b]{2}{*}{ LAND USES } & \multicolumn{2}{|c|}{ YEAR 1956} & \multicolumn{2}{|c|}{ YEAR 2011} \\
\hline & $\begin{array}{c}\text { Land surface } \\
\left(\mathbf{m}^{2}\right)\end{array}$ & $\begin{array}{l}\text { Land in } \\
\text { the basin } \\
(\%)\end{array}$ & $\begin{array}{l}\text { Land surface } \\
\left(\mathrm{m}^{2}\right)\end{array}$ & $\begin{array}{l}\text { Land in } \\
\text { the basin } \\
(\%)\end{array}$ \\
\hline Forest trees (Arbolado forestal) & $1.559 .649,30$ & 1,31 & $9.547 .013,91$ & 8,05 \\
\hline Crops (Cultivos) & $52.420 .766,14$ & 43,90 & $32.664 .580,78$ & 27,55 \\
\hline Scrubland (Matorral) & $6.148 .416,92$ & 5,15 & $13.631 .728,91$ & 11,50 \\
\hline Pastureland (Pastizal) & $51.585 .534,95$ & 43,20 & $47.279 .272,51$ & 39,88 \\
\hline $\begin{array}{l}\text { Beaches, dunes and sandy } \\
\text { beaches (Playas, dunas y } \\
\text { arenales) }\end{array}$ & $9.724,59$ & 0,01 & $4.811,21$ & 0,00 \\
\hline Dry riverbeds (Ramblas) & $1.410 .360,93$ & 1,18 & $676.283,40$ & 0,57 \\
\hline Hard rock (Roquedo) & 4.699.145,77 & 3,93 & $5.614 .041,92$ & 4,74 \\
\hline Artificial soil (Suelo artificial) & $1.062 .880,81$ & 0,89 & $6.971 .551,60$ & 5,88 \\
\hline Road network (Red Viaria) & $522.755,07$ & 0,44 & $643.515,65$ & 0,54 \\
\hline Burned areas (Zonas quemadas) & & & $1.524 .082,36$ & 1,29 \\
\hline TOTAL & $119.419 .234,48$ & 100,00 & 118.556.882,26 & 100,00 \\
\hline
\end{tabular}




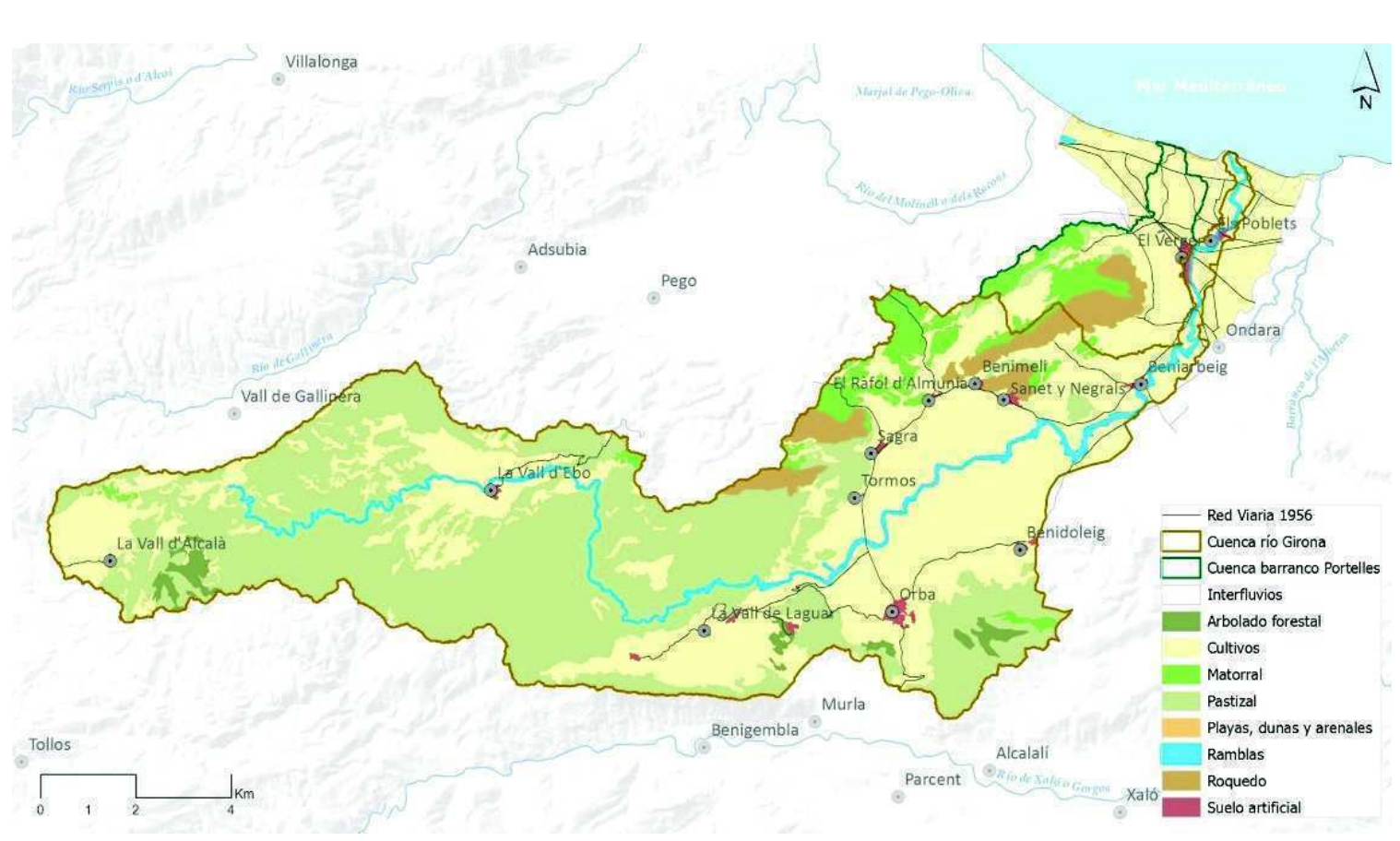

Figure 1.

Land uses in the basins of the Girona river and Portelles ravine in the year 1956. Source: Own elaboration from aerial photographs of the IGN and Cadastre.

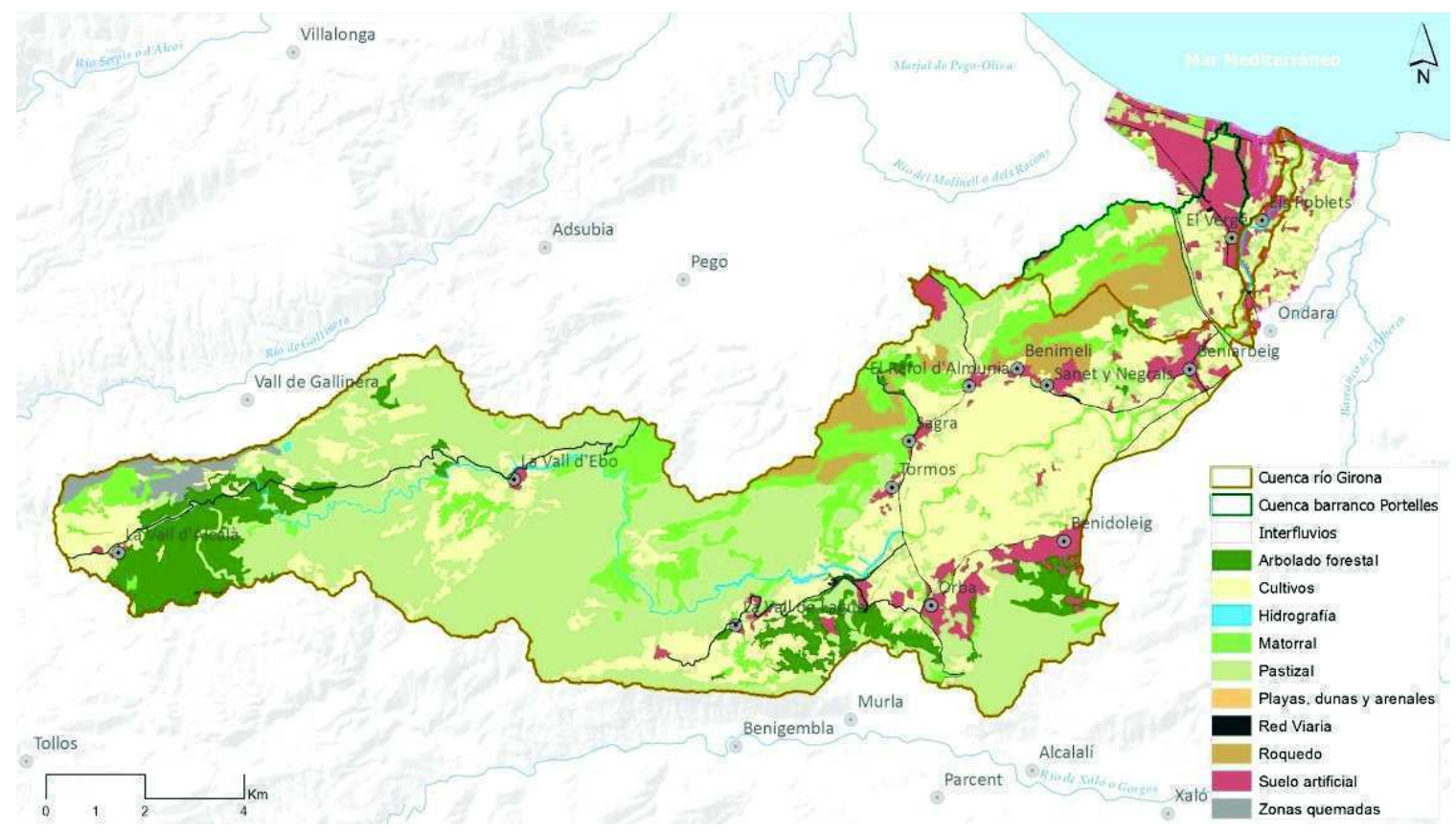

Figure 2.

Land uses in the basins of the Girona river and Portelles ravine in 2011. Source: Own elaboration based on cartography of the ICV.

The basins of the Girona river and the Portelles ravine have undergone important changes in the land uses in practically the 50 years considered in this investigation. Table 2 shows that the greatest change in absolute value has been the crop, with a reduction of around $20 \mathrm{~km} 2$, which has been $37,69 \%$ less cultivated area than in 1956. In The middle and upper stretches of the Girona river have produced a large part of the abandonment of 
terraces for primary rainfed crops, giving rise to the development of natural vegetation, both arboreal forest masses and scrubland.

Forest surface area has increased slightly above the surface of scrubland. However, compared to the surface of these same uses in 1956, there is a much higher development of forest trees, increasing by more than $500 \%$, in front to scrubland that increases by $121 \%$ with respect to the one existing in 1956.

The positive effects that occur in the basin due to the increase of the forest masses are offset by the negative effects of the considerable increase that the artificial soils have experienced, especially the building in areas susceptible to be dangerous in the face of floods. Artificial soil, including the road network, in 1956 barely represented $1,33 \%$ of the uses that were located in the basin, in 2011 it was at $6,42 \%$. The growth in the total area of the basin is of $5,09 \%$, but with respect to the surface that own use had in 1956, the increase is of more than $380 \%$, having transformed more than 6 million square meters of land, in front to one million almost six hundred thousand $(1.585 .636 \mathrm{~m} 2)$, existing in the initial year of reference.

The changes in land use experienced in the basin between 1956 and 2011 have changed the runoff generated. In order to estimate the runoff threshold ( $\mathrm{P} 0)$, it is necessary to identify the type of soil (due to its drainage capacity), soil cover, slope and moisture conditions predicted. Table 3 shows the average runoff threshold in the basins of the Girona river and the Portelles ravine, grouping the land uses, being higher in 2011.

Changes in land use, in particular the reduction of agricultural areas and the increase of forest areas have meant that the average runoff threshold at the research site has increased by nearly two points compared to 1956. Urban areas have increased significantly in the period analyzed, with an impact on the reduction of the average runoff threshold. This has been offset by the considerable increase in forest areas, by almost $20 \%$ with respect to those in the year 1956, with agricultural land being reduced by $38 \%$, compared to 1956 , in favor of forest and urban soils, as has been shown.

\section{Urban morphology}

In the analyzed area the density of houses in the municipalities of the mouth of the river Girona (Dènia and Els Poblets) is low, being dominant the model of occupation of the extensive territory. In the upstream municipalities, El Verger and Beniarbeig, the density of houses is average, with a greater number of multi-family

Table 2.

Variation in land use between 1956 and 2011. Source: Own elaboration.

\begin{tabular}{|l|r|c|}
\hline \multirow{2}{*}{ LAND USES } & \multicolumn{2}{|c|}{$\begin{array}{c}\text { VARIATION IN SOIL SURFACE } \\
\text { BETWEEN 1956 AND 2011 }\end{array}$} \\
\cline { 2 - 3 } & m $^{\mathbf{2}}$ & $\mathbf{\%}$ \\
\hline Arbolado forestal & $7.987 .364,60$ & 512,13 \\
\hline Forest trees (Arbolado forestal) & $-19.756 .185,36$ & $-37,69$ \\
\hline Crops (Cultivos) & $7.483 .312,00$ & 121,71 \\
\hline Scrubland (Matorral) & $-4.306 .262,44$ & $-8,35$ \\
\hline Pastureland (Pastizal) & $-4.913,38$ & $-50,53$ \\
\hline $\begin{array}{l}\text { Beaches, dunes and sandy beaches (Playas, } \\
\text { dunas y arenales) }\end{array}$ & $-734.077,53$ & $-52,05$ \\
\hline Dry riverbeds (Ramblas) & $914.896,15$ & 19,47 \\
\hline Hard rock (Roquedo) & $5.908 .670,79$ & 555,91 \\
\hline Artificial soil (Suelo artificial) & $120.760,58$ & 23,10 \\
\hline Road network (Red Viaria) & $1.524 .082,36$ & - \\
\hline Burned areas (Zonas quemadas) & & \\
\hline
\end{tabular}


Table 3.

Area and average runoff threshold in 1956 and 2011. Source: Own elaboration.

\begin{tabular}{|l|r|r|r|r|}
\hline \multirow{2}{*}{ LAND USES } & \multicolumn{2}{|c|}{ YEAR 1956 } & \multicolumn{2}{c|}{ YEAR 2011 } \\
\cline { 2 - 5 } & $\begin{array}{c}\text { Land surface } \\
\text { (ha) }\end{array}$ & $\mathbf{P}_{\mathbf{0}} \mathbf{( m m )}$ & $\begin{array}{c}\text { Land surface } \\
\text { (ha) }\end{array}$ & $\mathbf{P}_{\mathbf{0}}(\mathbf{m m})$ \\
\hline Urban areas & 158,56 & 0,05 & 761,51 & 0,23 \\
\hline Agricultural areas & $5.242,08$ & 8,43 & $3.266,46$ & 5,34 \\
\hline Forest and semi-natural areas & $6.541,28$ & 21,96 & $7.827,72$ & 26,62 \\
\hline TOTAL & $\mathbf{1 1 . 9 4 1 , 9 2}$ & $\mathbf{3 0 , 4 3}$ & $\mathbf{1 1 . 8 5 5 , 6 9}$ & $\mathbf{3 2 , 1 9}$ \\
\hline
\end{tabular}

buildings.

In addition to the density of houses, which explains the occupation model, the evolution of urban constructions has been analyzed, taking into account their location, as well as their exposure to flood risk.

Also, different flood scenarios have been considered in the analysis, which allowed to determine the degree of exposure of the studied constructions. In this way the following flood scenarios have been considered:

- T100 / CAL> 70: Equivalent to buildings affected by the flood corresponding to the return period of 100 years and depth greater than 70 centimeters.

- $\mathrm{T} 100 / \mathrm{CAL}=30-70$ : Equivalent to buildings affected by the flood corresponding to the return period of 100 years and depth between 30 and 70 centimeters.

- T25: Corresponds to buildings affected by the flood envelope for the 25 -year return period.

- T100: Corresponds to buildings affected by the flood envelope for the return period of 100 years (includes the two initial scenarios).

- T500: Corresponds to buildings affected by the flood envelope for the 500-year return period.

- PREF FLOW: corresponds to the buildings affected by the flood envelope of the preferential flow defined in accordance with Article 9 of the Regulation of the Public Hydraulic Domain, approved by Royal Decree 849/1986, of April 11, and modified by the Royal Decree 9/2008, of 11 January.

In order to be able to compare the buildings affected by flood risk from those not affected, a scenario of all constructions carried out in the municipality, both affected and not affected, has been identified as TOTAL CONST.

For the development of the work, data sources have been used of the General Direction of Cadastre and the National System of Mapping of Flood Zones (SNCZI).

With the information available and through geographic information systems, new layers were generated with information on the built surface affected by flood and the year of construction for each of the previous scenarios.

Results and graphs were obtained for all municipalities in the basin, however, by way of example, the municipality of Els Poblets (Figure 3 and Figure 1) are shown.

The municipality of Els Poblets, one of the most affected by flood hazard, experienced its greatest increase in construction since 1977 (Figure 3). In this year the total constructed area was almost $12 \%$ of the existing one in the year 2013. In the year 1990 had been reached almost $72 \%$ of the total constructions. The built area continued to grow at a slightly slower pace, and it is from 2009 when the activity of the new construction is virtually paralyzed.

If we consider in the analysis the different scenarios considered in terms of flooding, it is observed that the constructed area affected by the scenarios $\mathrm{T} 100 / \mathrm{CAL}>70, \mathrm{~T} 100 / \mathrm{CAL}=30$ 70 and PREF. FLOW, reaches maximum values in 2013, almost $14 \%$ for this latter, being around $8 \%$ for the $\mathrm{T} 100 / \mathrm{CAL}>70$ scenario and $0,3 \%$ for the $\mathrm{T} 100 / \mathrm{CAL}=30-70$ scenario, as can be seen in Figure 4.

These results indicate that the constructed areas affected by a return period of 100 years and depth of more than $30 \mathrm{~cm}$ are very small in the scope of the municipal term of Els Poblets, being able to study solutions that are integrated in the urban network, making use 


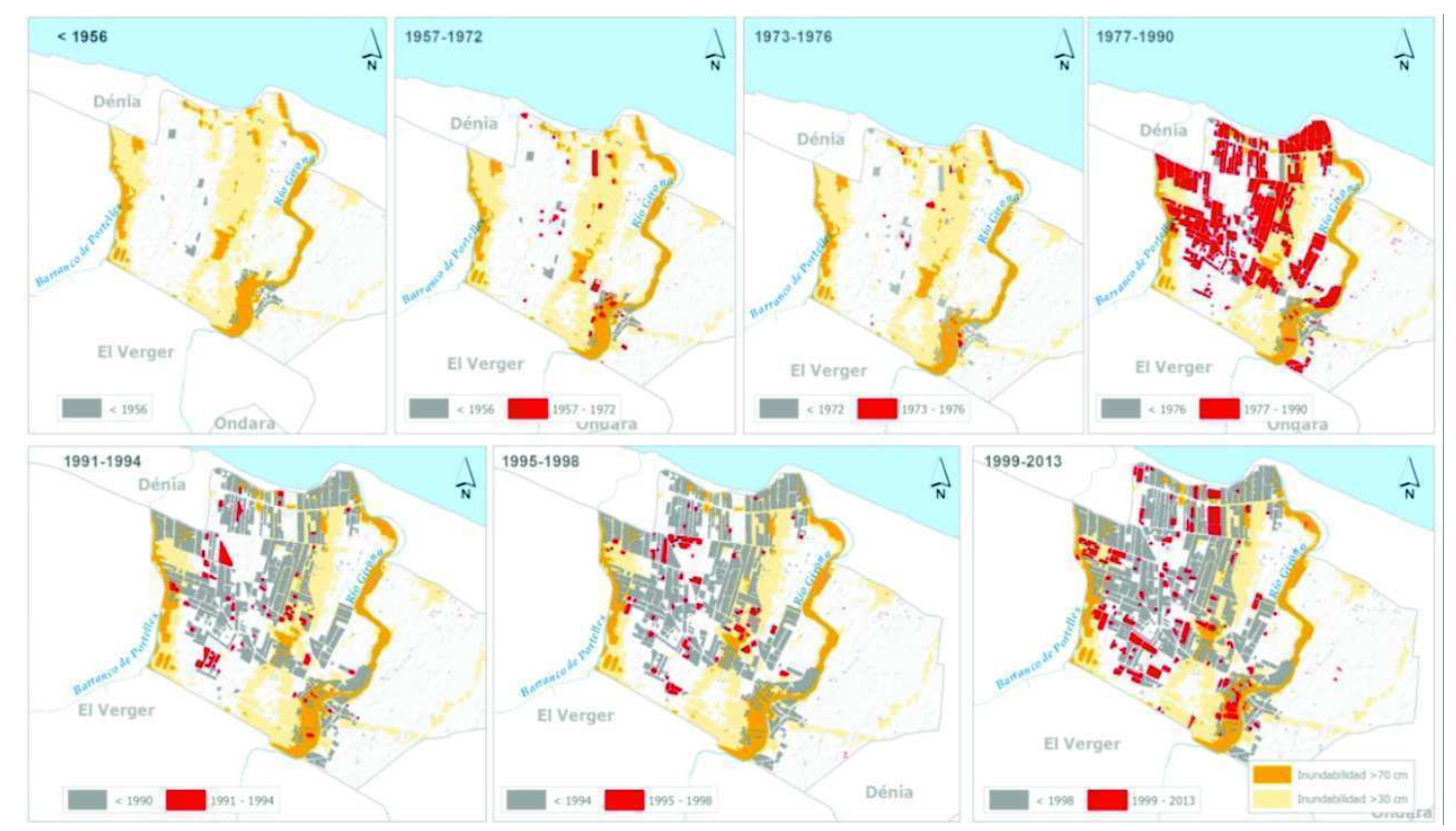

Figure 3.

Urban evolution of the municipality of Els Poblets between 1956 and 2013 and its flooding condition for the 100-year return period (T100). Source: Own elaboration based on the General Direction of the Cadastre and the Hydrographic Confederation of the Júcar.

of the developable or urban soils that have not yet been built. It is noteworthy that of the $83 \%$ of the constructed area affected by floods of T100, almost $75 \%$ presents depths smaller than $30 \mathrm{~cm}$. This circumstance allows to propose measures of protection of individual character on the constructions, improving the resilience of the same ones.

In the area affected by this research in the municipality of Denia, a behavior similar to that of Els Poblets has been observed, both in terms of the evolution of buildings and the different scenarios considered. The period of greatest growth in buildings was between 1977 and 1990. In this case the percentage of area affected within the basins studied for each of the scenarios is somewhat lower than that of Els Poblets, reaching $8,5 \%$ the priority flow, $8,10 \%$ the $\mathrm{T} 100 / \mathrm{CAL}>70$ and $0,25 \%$ the $\mathrm{T} 100 /$ $\mathrm{CAL}=30-70$. Again, $64 \%$ of the surface area affected by the T100 reaches depths of less than $30 \mathrm{~cm}$, being able to apply individual protection measures that increase the resilience of the constructions.

The municipality of El Verger presents a similar behavior to the two previous ones, but with a growth in the constructed surface that begins before, in the year 1972, being a smoother growth than the previous ones, so that in the year 1972, El Verger had built $26 \%$ of the surface area of the year 2013, it had reached $56 \%$ in 1999 , that is to say, for 27 years, $30 \%$ of the current constructed area. From 1999 on, there was an accelerated growth until 2009, in which almost $99 \%$ of the current constructed area was built, that is to say in ten years the municipality of El Verger has consolidated $43 \%$ of the area corresponding to urban constructions. However, the percentage of surface area built on the priority flow flood is less than $5 \%$, practically the same as for the $\mathrm{T} 100>70$ scenario, being insignificant for the scenario $\mathrm{T} 100 / \mathrm{CAL}=30-70$.

For the three cases analyzed, the scenario of T500 shows a condition on very high constructed surfaces, being between $81 \%$ and $87 \%$ of the total constructed area. However, a more detailed analysis would be required for the T100, in order to discretize the depths and, where appropriate, the most appropriate measures.

As for the growth model, Beniarbeig has followed a pattern similar to El Verger, and since 2000 it has increased its growth, concentrating $45 \%$ of it between 2000 and 2010. In Beniarbeig, for the T500 scenario, the 


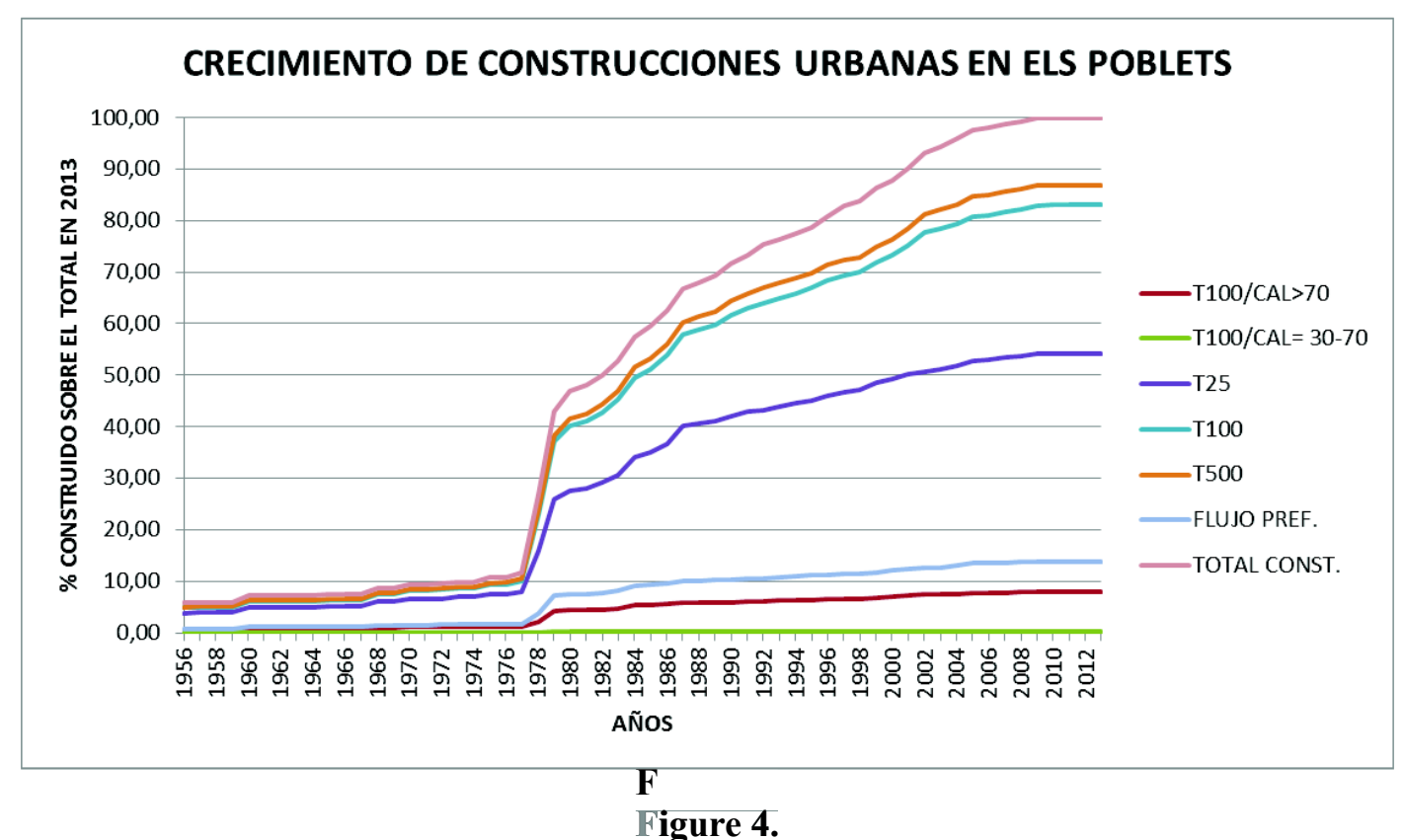

Evolution of the urban construction area of the municipality of Els Poblets between 1956 and 2013 and its flooding condition for different scenarios Source: Own elaboration based on the General Direction of the Cadastre and the Hydrographic Confederation of the Júcar.

condition on the built surfaces is smaller than in the previous cases, with $17,61 \%$ of the total constructed area. However, the constructed areas affected by priority flow are high, of the same order as in the previous municipalities, $7,82 \%$. The rest of buildings are punctually affected, relocation being the best measure, allowing the integration of the riverbeds with the urban environment.

\section{Conclusion}

The conditions regarding the production of runoff have improved in the basin analyzed, as the average runoff threshold has been increased as it has been seen, however, the damages currently produced are higher as a consequence of the increase in the risk exposure of people and their property. This situation can be worsened if the forest masses were reduced to the levels of the year 1956.

Analyzed the dynamics in the growth of the urban constructions in the municipalities of the scope of this research affected by some of the flood scenarios defined above, it has been observed that in general, those who have been more dynamic have shown similar patterns increasing the surface of buildings affected by flood. However, the percentage of the constructed area affected by a return period of 100 years and depths of more than $30 \mathrm{~cm}$ is sufficiently low in proportion to the total constructed area, which should oblige the competent authorities in the matter of spatial planning and urbanism to study possible solutions related to the urban morphology that integrate the model of occupation that they have developed with the management of the floods.

Likewise, it has been shown that most of the undue occupations on flood areas could have been avoided for return periods of 100 years and depths greater than $30 \mathrm{~cm}$, due to the small area they occupy. Flooded areas with very low depth and medium-low frequency (100500 years of return period) are more difficult to avoid due to their large extent, particularly in the municipalities located in the alluvial plain such as Els Poblets, Denia and El Verger. However, the adoption of particular measures on buildings and avoid taking flooded soils as those considered in the T100/CAL $>70, \mathrm{~T} 100 /$ $\mathrm{CAL}=30-70$ and scenarios FLOW PREF., would have considerably reduced the risks of these municipalities. 


\section{References}

Bussi, G., Ortiz, E., Francés, F., Pujol, L., Gabladón, R., Guna, V., y otros. (s.f.). Modelación hidráulica y análisis del riesgo de inundación según las líneas guía de la Directiva Marco del Agua. El caso de la Marina Alta y la Marina Baja (Alicante).

CVOPVT: Plan de Acción Territorial sobre prevención del Riesgo de Inundación en la Comunidad Valenciana (PATRICOVA) (2015). Consellería de Vivienda, Obras Públicas y Vertebración del Territorio, Dirección General de Ordenación del Territorio, Urbanismo y Paisaje.

European Union (2013). Guidance for Reporting under the Floods Directive (2007/60/EC). Guidance Document No. 29. Office for Official Publications of the European Communities.

Jha, A., Bloch, R., \& Lamond, J. (2012). Cities and Flooding. A guide to integrates urban flood risk management for 21 st Century. Washington D.C.: GFDRR.

Reddish, James. (2014). Flood risk and planning regulations. Lessons from the UK. Opus International Consultants Ltd.

Sayers, P., L.i, Y., Galloway, G., PenningRowsell, E., Shen, F., Wen, K., Chen, Y. and Le Quesne, T. (2013). Flood Risk Management: A Strategic Approach. Paris, UNESCO.

Segura Beltrán, F. (2009). Geomorfología, inundaciones y alteración antrópica del espacio inundable: El caso del Riu Girona (Alacant, Octubre de 2007). Boletín de la A.G.E.(49), 83-103. 